\title{
Level of Knowledge and Wound Care Practice at a Tertiary Referral Hospital in Ethiopia: A Survey in 180 Nurses
}

melak desta ( $\triangle$ melakd2018@gmail.com )

Debre Markos University College of Health Science https://orcid.org/0000-0002-4955-2346

Manaye Tenaw

Finoteselam Hospital

Emiru Ayalew

Bahir Dar University

\section{Research}

Keywords: wound healing, wound care knowledge, wound care practice

Posted Date: December 2nd, 2020

DOI: https://doi.org/10.21203/rs.3.rs-110089/v1

License: (ㅇ) (1) This work is licensed under a Creative Commons Attribution 4.0 International License. Read Full License 


\section{Abstract}

\section{Background}

Wound infections are a global public health challenge, a major cause of morbidity and mortality in low- and middle-income countries. Poor wound care results delayed wound healing process and wound infections. Improving the knowledge and practice of wound care is paramount to reduce wound infection. However, there is no study done in Ethiopia. This study was aimed to assess the knowledge and practices of nurses who worked at Felege Hiwot Specialized Hospital towards wound healing and care.

Methods

A survey was conducted among 180 nurses worked in Felegehiwot specialized hospital during January 1 to 30 , 2018. The study participants were selected through simple random sampling technique. Descriptive statistics were used to describe the study participants. Both Bivariable and multivariable ordinal logistic regression was done and proportional odds ratio (POR) with a 95\% confidence interval $(\mathrm{Cl})$ was reported to show the strength of association. A p-value $<0.05$ was used to declare statistically significant.

Result

In this study, $34(18.7 \%)$ and $17(9.3 \%)$ of nurses have a good knowledge and practice on wound healing and care. While $41.8 \%$ and nearly three-fourths $(60 \%)$ of the participants have a poor level of knowledge and practice on wound care respectively. Working experience of fewer than 5 years (aPOR 0.42, 95\% Cl: 1.11, 2.72), working in the surgical ward (aPOR $5.45,95 \% \mathrm{Cl}: 1.61,2.21$ ) and in the emergency department (aPOR, 0.26, $95 \% \mathrm{Cl}: 0.03,0.18$ ) were significant factors of knowledge of wound care. While, get training (aPOR $1.9,95 \% \mathrm{Cl}$ : $0.59,0.87$ ) and good knowledge (aPOR $5.56,95 \% \mathrm{Cl}: 1.08,2.26)$ on wound care increased the level of practice.

Conclusions

The knowledge and practice of wound care of nurses were found to be poor. Above two-fifth of nurses doesn't provide predischarge education on wound care. For this, provision of a structured preservice and in-service training and education program on wound healing and care, improve nurses educational level or experience sharing, establish and put in place wound healing and care guideline and assessment tools in hospitals and conduct the further qualitative study the level of wound care practice was recommended.

\section{Background}

Wound infections acquired during health care delivery are a global public health challenge, the commonest causes of nosocomial infections accounted to $20 \%$ to $25 \%$ [1] and leads to sepsis, a life-threatening organ dysfunction caused by a dysregulated host response to infection [2]. It is a major cause of the increasing cost due to extended hospitalization $[3,4]$, morbidity [5] and mortality particularly in low- and middle-income countries $[6,7]$.

Wound infection resulted due to the disturbance of the wound healing process that must occur in the proper order, at a specific time, and continue for a specific duration at an optimal intensity [1]. Wounds are physical 
injuries that cause a disturbance in the normal skin anatomy and function and many factors can affect wound healing, [4, 8-11] causing impaired tissue repair.

Wound site infections occurred approximately $2 \%$ to $5 \%$ of the 16 million patients undergoing surgery in united states [1] , 22.2 \% in Switzerland [12] and are the leading cause of infections in developing countries due to scarce resources and health professionals [13], wound cultures resistant to first-line antimicrobials[14, 15], and poor quality of health care [16]. Antibiotic-resistant wound infections were common sub-Saharan Africa, mainly Tanzania (63\%) [17, 18], Benin (34.6\%), Congo (31.9\%), Togo (14.3\%), Madagascar (14.5\%) [14] and 7\% in Kenya [19].

Proper wound care is one the major preventive majors of wound infections [20-23], the world health organization (WHO) calls to prevent healthcare-associated sepsis with a simple cost effective practice such as hand hygiene $[24,25]$. The nurses' knowledge regarding wound care and the interventions provided at an early stage is important for wound healing and all surgical wounds require special nursing care both at the hospital or at home[26-31].

Assessing the knowledge and practice of wound care is paramount to reduce wound infection. Better knowledge of wound care decreases surgical complications, repeated admissions, hospitalization duration, and improves the quality of life [32]. The incidence rate of wound infection is still higher in Ethiopia, 10.9 to $75 \%[15,33,34]$ and in this hospital [34]. However, there is no study done on the knowledge and practice of wound healing and care at the national and regional level. Therefore, this study was conducted to assess the knowledge and practices of nurse professionals working at Felege Hiwot tertiary referral hospital, regarding wound healing.

\section{Methods}

\section{Study Area, design and period}

A survey was conducted from January 1 to 30, 2018 in Felege Hiwot tertiary referral hospital found in Bahir Dar city. Bahir Dar is a capital city in the Amhara region in the Northwest of Ethiopia about $578 \mathrm{~km}$ from Addis Ababa and is one of the leading tourist destinations in Ethiopia, nearby Lake Tana and Blue Nile River [35]. In the city, there are 12 public health facilities, 10 health centres and 2 hospitals. The hospital is a tertiary hospital, serving over 7 million people as the referral centre and has around 400 beds and 9 operating tables and 750 members of staff and among those 292 are nurses. The hospital provides obstetrics, paediatrics, internal medicine, ophthalmology, ENT and surgery services [36].

\section{Population and sampling}

Source populations were all nurses who work in Felege Hiwot hospital. All sampled nurses of Felege Hiwot hospital who selected in a simple randomly technique will be included and nurse managers were excluded. The 
total number of representative sample was selected using a single population formula as follows:

$$
\mathrm{n}=\underline{(\mathrm{Z} \alpha / 2)^{2} \mathrm{p}(1-\mathrm{p})}
$$

$\mathrm{w}^{2}$

Where $n=$ minimum sample size required for the study, $(Z=1.96)$ with confidence interval of $95 \%$ and $a=0.05$, $P=$ prevalence $(p=0.5), w=$ is a tolerable margin of error $(w=0.05)$. Using the correction formula with a $10 \%$ nonresponse rate, 182 was the final sample size. Stratified with Simple random sampling method was used by using the sampling frame which found from the head of nurses/ matron.

\section{Variables and measurements}

The dependent variables were knowledge and practice of wound care and the independent variables included were sociodemographic factors (age, occupation, educational background, marital status and facility-related factors (working area, and training on wound care).

Good Knowledge: participants who answer more than $80 \%$ of the knowledge questions correctly.

Moderate knowledge: those study participants who answer $60-79 \%$ of the knowledge question correctly.

Poor knowledge: those study participants who answer less than $60 \%$ of the knowledge questions correctly.

Good Practice: those study participants who correctly respond to practice questions and score above $80 \%$

Moderate practice: those study participants who correctly respond to practice questions score $60-79 \%$.

Poor Practice: study participants who correctly respond to practice questions score below 60\% [37]. Data collection procedure and quality control

The data was collected using self-administered structured questionnaires adopted from different related kinds of literature [38-40] and modified in our context. A questionnaire was prepared in English and translated into the local language, and back to English for consistency. Two nursing staffs were collecting the data and one senior staff was recruited as supervisors and pretest was conducted in Finote Selam hospital on $5 \%$ of sample size. The data were checked daily basis for completeness and consistency.

\section{Data processing and analysis}

Data were entered and analyzed using SPSS version 23 and descriptive analysis such as percentages, frequency distribution was used. The bi-variable and multi-variable proportional odds model (POM), was fitted to assess factors associated with knowledge and practice of wound healing and care. Chi-square parallel line tests were checked ( $p$-value $=0.46$ ), indicating that the assumption was not violated. Model fitness using the chi-square goodness-of-fit test $(p=0.152)$ was checked. All variables with a $p$-value $\leq 0.25$ in the bivariable analysis were entered into the multivariable analysis to control the confounding effect. Adjusted proportional odds ratio (POR) with a 95\% $\mathrm{Cl}$ was used to assess the association between explanatory and outcome 
variables. Variables with p-values $<0.05$ in the multivariable analysis were considered to be statistically significant. The analysis was done by reporting of STROBE statement checklist [41].

\section{Ethical consideration}

Ethical clearance was obtained from Bahir Dar University, department of nursing. A formal letter was written to Bahir Dar specialized Hospital and permission was secured from the medical director. All study participants were informed that they have the right not to participate in the study or stop the interview at any time they want if that was their choice. Written consent was obtained from all participants before the interview. All information obtained in the study was stored confidential and secured.

\section{Results}

\section{Socio-demographic characteristics of the participants}

A total of 182 nurses worked in Felegehiwot comprehensive specialized hospital were participated in the study making a response rate of $100 \%$. Ninety-six, $(52.7 \%)$ were females and two-third, $(67.6 \%)$ of the participants was found within the age range of 20-30. Almost half, $(47.8 \%)$ of nurse professionals were served from one to five years and $138(75.8 \%)$ had a bachelor degree in nursing. Most of the respondents, $132(72.5 \%)$ does not get training about wound healing and care (Table 1).

\section{Level of knowledge of nurses regarding wound care}

The study had found that 34 (18.7\%) of the respondents have a good knowledge and two-fifth, $(41.8 \%)$ of the nurses had poor knowledge of wound healing and care. The majority $172(94.5 \%)$ knows as immobility, impaired nutrition, and location of the wound are risk factors for wound infection. Similarly, $118(64.8 \%)$ knows as wet therapy is the "gold standard" for treating chronic wounds and $127(69.8 \%)$ of the respondents know the pain in the wound must be evaluated by the patient than the healthcare providers. One hundred and thirty (71.4\%) know the selection of the coverage of the wound should be based on a characteristic of the deathbed. Only half of $100(54.9 \%)$ of the respondents have known as the first stage of pressure ulcer is cannot easily identify in people of dark skin and $135(74.2 \%)$ respondents know as irrigation removes debris from wound better than swabbing (Table 2).

\section{Level of the practice of nurses on wound care}

This study found, 109 (59.9\%) of the respondents had poor and $17(9.3 \%)$ of nurses have a good level of practice on wound healing and care (Figure 2). Forty-one (22.5\%) of the participants were using the same dressing type for the entire wound healing time usually and almost half (48.9\%) nurses change the treatment plan always when the wound fills with granulation tissue and epithelization.

Regarding the wound cleansing, more than half (57.8\%) used normal saline always, 79 (43.4\%) of nurses used hydrogen peroxide for sometimes and a large proportion (74.2\%) were never used water for wound cleansing. 
The majority, $62.6 \%$ and $61 \%$ of the participants positioning the wound and observing the wound on daily flow, rush, and temperature respectively and above two-thirds $(68.1 \%)$ of nurses provide suggestions about nutrition for the patient always (Table3). Regarding the predischarge education, $144(79.1 \%)$ of the participants informing about wound care always, mainly about the food groups for faster wound healing $(67.0 \%)$ and 119 $(65.4 \%)$ of them provide education on hygiene to prevent infection on the incision area (Table 4).

\section{Associated factors of the level of knowledge and practice of wound care}

In a bivariate proportional ordinal regression sex, working experience in this hospital, the clinical setting in this center and training on wound care was associated with knowledge of the wound care. But in multivariable regression, only working experience and clinical setting in this center was significantly associated with the level of knowledge of nurses on wound care.

Those nurses who have working experience of fewer than 5 years in this hospital has $58 \%$ times less likely to have a good knowledge (aPOR $0.42,95 \% \mathrm{Cl}: 1.11,2.72$ ) than those working years 10 years and above. On the other hand, those working in the surgical setting or ward were five and a half times greater chance of to have a good level of knowledge level (aPOR $5.45,95 \% \mathrm{Cl}: 1.61,2.21$ ) and those working in the emergency ward were 74 times less likely (aPOR, $0.26,95 \% \mathrm{Cl}: 0.03,0.18)$ to have better knowledge than their counterparts.

Age, clinical experience, working experience in this center, clinical setting, training on wound care and level of knowledge in wound care were included in the multivariable ordinal logistic regression. But training and the level of knowledge of wound care were the only remaining significant factors of the practice of wound care. Those nurses who have to get training on wound care were 2 times higher odds of performing the good level of practice of wound healing and care than those who haven't get training ( aPOR 1.9, 95\% Cl: 0.59, 0.87). On the other hand, those women who have a good level of knowledge on wound care were five and a half times greater chance of attaining a good level of practice than their counterparts (aPOR 5.56, 95\% Cl: 1.08, 2.26).

\section{Discussion}

Wound infection the commonest cause of nosocomial infection in healthcare and prevention with proper wound care is important. This study investigated the knowledge and practice of nurses towards wound healing and cares. About the level of nurse's knowledge on wound healing and care, the result of this study showed that $18.7 \%$ of the participants had good knowledge but a large proportion ( $41 \%)$ of participants have a poor level of knowledge. This was much lower than the studies conducted in Australia, 34.7\% [42] Brazil, 69.4\% [38], United Kingdom, 44.1\% [43] and France, 28\% [44] have good knowledge of wound care in respectively. The possible difference might be due to socio-demographic, clinical the setting, sample size and methodological difference and also the poor quality of care in our setting due to limited resources. Despite, this finding is better than a study done in Nigeria [45], only $6 \%$ had good knowledge.

The majority $172(94.5 \%)$ of the respondents have good knowledge of the immobility; impaired nutrition, and location of the wound are risk factors for wound infection. This study revealed that wound healing and care practice of nurses was very poor, 9.3\%. The result of this study is similar a study done in Nigeria [45]. However, 
this is lower than the United Kingdom's finding [43], 40\% and Turkey's [39], 50\% of nurses have better practice on wound healing and care practice. This discrepancy might be because of socio-demographic, training and knowledge difference on wound care. In this study, it was found that $40.6 \%$ of the nurses did not provide predischarge education about wound healing regularly on the discharge of the patient, similar to a Turkish study [39]. Hence, patients discharged to home without the required knowledge and skill for care at home leads to physical and psychological stress.

This study revealed that the length of working experience was associated with knowledge of wound care. It showed the lower the year of experience, the lower the level of knowledge. This is supported by another study $[43,46]$. This might be since those who have lower years of working experience have lower chance to work with different experienced professionals not learn from their coworker's experience and prevents to gain acquired knowledge of wound care. The clinical setting difference is one of the factors of knowledge of wound healing and care, showed that those working at the surgical ward were more knowledgeable and those working in the emergency department were less knowledgeable. This is supported by a study done in Denmark[47] and the United Kingdom [48], knowledge varies as the role of nurses varies. This might be wound care would be expected to be performed routinely in everyday practice in the surgical ward than others which will increase their knowledge and lack of training for all staff providers and source on another ward might be explained for lower knowledge.

Furthermore, this finding showed that those nurses who have training on wound care have a higher level of practice than their counterparts. This is in line with other studies $[43,49,50]$. The possible explanation for this might be that those who have taken training would be more likely to be knowledgeable with the updated information, leads to the practice of the acquired evidence. Knowledge of wound care was the most predictor of wound healing and care practice, in which those professionals have good knowledge, were more likely to practice based on the recommendations. This is supported by different studies $[43,48,51,52]$. This might be explained due to hat the level of knowledge in the care of patients with wounds can reflect on their practice and influence of the other members of the nursing team, their self-assessment of competence on the wound will be higher when they had increased their wound care knowledge, enhanced their practice of the evidence-based practice of wound care.

Even several extensive have been made to reduce the limitations; the study subjects in this study only included government hospitals and unable to a representative for private hospitals. The cross-sectional nature of this study will make it unable to form a temporal relationship between the outcome and predictor variables. The study is also prone to social desirability bias which could lead to over/underestimation of the study found hence it was self-reporting by the participants.

\section{Conclusions}

The knowledge and practice of wound care of nurses were found to be poor. Above two-fifth of nurses doesn't provide predischarge education on wound care. For this, provision of a structured preservice and in-service training and education programs on wound healing and care, improve nurses educational level or experience sharing, establish and put in place wound healing and care guideline and assessment tools in hospitals and conduct further qualitative study the level of wound care practice was recommended. 


\section{Abbreviations}

SPSS Social package Statically Software

APOR Adjusted Proportional Odds Ratio

\section{Declarations}

\section{Acknowledgement}

Authors are thankful for Bahir Dar University and hospital health workers.

\section{Ethics approval and consent to participate}

The study protocol was reviewed and approved by Bahir Dar University Research Ethics Review Committee. The official letter of cooperation was obtained from the College of Medicine and Health Science in Bahir Dar specialized Hospital and permission was secured from the medical director. All study participants were informed that they have a right not to participate in the study or stop the interview at any time they want if that was their choice. Written consent was obtained from all participants before the interview. All information obtained in the study was stored confidential and secured.

Consent to publication: Not applicable.

\section{Availability of data and materials}

The data sets used and analyzed during the current study are available from the corresponding author on reasonable request.

Competing interest: the authors declare that they have no competing interests

Funding: No funding sources

\section{Authors' Contributions}

MT and EA conceived and designed the study, supervised the data collection, and analsized the data. MD* assisted in designing the study, reviewed and analyzed the study, and wrote up the manuscript. All authors read and approved the final manuscript.

\section{Author's information}

${ }^{1}$ BSC Nursing health professional, Finote Selam hospital, Finote Selam, Amhara region, Ethiopia

2 Department of Nursing, MSc in Emergency nursing, Debre Markos University, Debre Markos, Ethiopia

${ }^{3}$ Department of Midwifery, MSc in midwifery, Debre Markos University, Debre Markos, Ethiopia

\section{References}


1. Gosain, A. and L.A. DiPietro, Aging and wound healing. World journal of surgery, 2004. 28(3): p. 321-326.

2. Singer M, D.C., Seymour CW, Shankar-Hari M, Annane D, Bauer M, et al,, The Third International Consensus Definitions for Sepsis and Septic Shock (Sepsis-3). JAMA 2016. 315: p. 801-10.

3. Sgonc, R. and J. Gruber, Age-related aspects of cutaneous wound healing: a mini-review. Gerontology, 2013. 59(2): p. 159-64.

4. Trexler, R.A., Assessment of surgical wounds in the home health patient: definitions and accuracy with OASIS-C. Home Healthcare Now, 2011. 29(9): p. 550-559.

5. Cassini, A., et al., Burden of Six Healthcare-Associated Infections on European Population Health: Estimating Incidence-Based Disability-Adjusted Life Years through a Population Prevalence-Based Modelling Study. PLoS Med, 2016. 13(10): p. e1002150.

6. Fleischmann C, S.A., Adhikari NKJ, Hartog CS, Tsaganos T, Schlattmann P et al,, Global sepsis incidence and mortality of hospital-treated sepsis. . Am J Respir Crit Care Med, 2016. 103(259-272).

7. Alp, E. and N. Damani, Healthcare-associated infections in intensive care units: epidemiology and infection control in low-to-middle income countries. J Infect Dev Ctries, 2015. 9(10): p. 1040-5.

8. Kumari, P., et al., A review on wound healing properties of Indian medicinal plants. Ind J Fund Appl Life Sci, 2013. 3(1): p. 220-32.

9. Mathieu, D., J.-C. Linke, and F. Wattel, Non-healing wounds, in Handbook on hyperbaric medicine. 2006, Springer. p. 401-428.

10. Pathak, A., et al., Incidence and factors associated with surgical site infections in a teaching hospital in Ujjain, India. Am J Infect Control, 2014. 42(1): p. e11-5.

11. Tariq, A., et al., Assesment of predictor variables and clinical consequences associated with surgical site infection in tertiary care setting, Karachi, Pakistan. Pak J Pharm Sci, 2018. 31(1(Suppl.)): p. 269-275.

12. Metsini, A., et al., Point prevalence of healthcare-associated infections and antibiotic use in three large Swiss acute-care hospitals. Swiss Med Wkly, 2018. 148: p. w14617.

13. Allegranzi, B., et al., Burden of endemic health-care-associated infection in developing countries: systematic review and meta-analysis. Lancet, 2011. 377(9761): p. 228-41.

14. Lai, P.S., et al., Epidemiology of antibiotic-resistant wound infections from six countries in Africa. BMJ Glob Health, 2017. 2(Suppl 4): p. e000475.

15. Mengesha, R.E., et al., Aerobic bacteria in post surgical wound infections and pattern of their antimicrobial susceptibility in Ayder Teaching and Referral Hospital, Mekelle, Ethiopia. BMC Res Notes, 2014. 7: p. 575.

16. Schütte, S., P.N.M. Acevedo, and A. Flahault, Health systems around the world-a comparison of existing health system rankings. Journal of global health, 2018. 8(1).

17. Manyahi, J., et al., Predominance of multi-drug resistant bacterial pathogens causing surgical site infections in Muhimbili National Hospital, Tanzania. BMC Res Notes, 2014. 7: p. 500.

18. Kassam, N.A., et al., Spectrum and antibiogram of bacteria isolated from patients presenting with infected wounds in a Tertiary Hospital, northern Tanzania. BMC Res Notes, 2017. 10(1): p. 757.

19. Dinda, V., et al., Pattern of pathogens and their sensitivity isolated from surgical site infections at the Aga Khan University Hospital, Nairobi, Kenya. Ethiop J Health Sci, 2013. 23(2): p. 141-9. 
20. Price, R., E. Makasa, and M. Hollands, World Health Assembly Resolution WHA68. 15:"strengthening emergency and essential surgical care and anesthesia as a component of universal health coverage"addressing the public health gaps arising from lack of safe, affordable and accessible surgical and anesthetic services. World journal of surgery, 2015. 39(9): p. 2115-2125.

21. Wong, C.S. and E.H. Aly, The effects of enteral immunonutrition in upper gastrointestinal surgery: $A$ systematic review and meta-analysis. Int J Surg, 2016. 29: p. 137-50.

22. Moussa, W.M. and M.A. Mohamed, Efficacy of postoperative antibiotic injection in and around ventriculoperitoneal shunt in reduction of shunt infection: A randomized controlled trial. Clin Neurol Neurosurg, 2016. 143: p. 144-9.

23. Sharma, G., et al., In search of the optimal wound dressing material following total hip and knee arthroplasty: a systematic review and meta-analysis. Int Orthop, 2017. 41(7): p. 1295-1305.

24. Peters, A., et al., Let's prevent sepsis in health care - The 5 May 2018 World Health Organization (WHO) SAVE LIVES: Clean Your Hands campaign. J Infect, 2018. 76(6): p. 563-569.

25. Saito, H., et al., It's in your hands: prevent sepsis in health care, May 52018 World Health Organization SAVE LIVES: Clean Your Hands campaign. American Journal of Infection Control, 2018. 46(5): p. 480-481.

26. Thomson, $\mathrm{H}$., et al., Housing improvements for health and associated socio-economic outcomes. Cochrane Database Syst Rev, 2013(2): p. Cd008657.

27. Adkins, C.L., Wound care dressings and choices for care of wounds in the home. Home Healthc Nurse, 2013. 31(5): p. 259-67; quiz 268-9.

28. Benbow, M., Wound care: ensuring a holistic and collaborative assessment. British Journal of Community Nursing, 2011. 16(Sup9): p. S6-S16.

29. Barksdale, P. and J. Backer, Health-related stressors experienced by patients who underwent total knee replacement seven days after being discharged home. Orthop Nurs, 2005. 24(5): p. 336-42.

30. Cebeci, F. and S.S. Celik, Discharge training and counselling increase self-care ability and reduce postdischarge problems in CABG patients. J Clin Nurs, 2008. 17(3): p. 412-20.

31. Oberst, M.T. and D.W. Scott, Postdischarge distress in surgically treated cancer patients and their spouses. Res Nurs Health, 1988. 11(4): p. 223-33.

32. Magalhães, M.G.P.d.A., et al., Post-operative mediastinitis in a Heart Hospital of Recife: contributions for nursing care. Revista da Escola de Enfermagem da USP, 2012. 46(4): p. 865-871.

33. Legesse Laloto, T., D. Hiko Gemeda, and S.H. Abdella, Incidence and predictors of surgical site infection in Ethiopia: prospective cohort. BMC Infect Dis, 2017. 17(1): p. 119.

34. Mulu, W., et al., Associated Risk factors for Postoperative Nosocomial infections among Patients admitted at Felege Hiwot Referral Hospital, Bahir Dar, Northwest Ethiopia. Clin Med Res, 2013. 2(6): p. 140-7.

35. . Http://www.laketana-biosphere reserve .com.Ethiopia.

36. https://www.aagbi.org/sites/default/files/Jolene_Moore_IRC_Report_Ethiopia.pdf.

37. Famakinwa, T., et al., Knowledge and practice of post-operative wound infection prevention among nurses in the surgical unit of a teaching hospital in Nigeria. International Journal of Basic, Applied and Innovative Research, 2014. 3(1): p. 23-28. 
38. Ferreira, A.M., et al., Knowledge and practice of nurses about care for patients with wounds. Revista de Pesquisa: Cuidado é Fundamental Online, 2014. 6(3): p. 1178-1190.

39. Surme, Y., P.T. Kartin, and G.N. Curuk, Knowledge and Practices of Nurses Regarding Wound Healing. J Perianesth Nurs, 2018. 33(4): p. 471-478.

40. Ademola, S.A., Commentary on 'Nurses reported practices and knowledge of wound assessment, assessment tools and documentation in a selected hospital in Lagos, Nigeria'. Afr J Med Med Sci, 2014. 43(2): p. 158-9.

41. Von Elm, E., et al., The Strengthening the Reporting of Observational Studies in Epidemiology (STROBE) Statement: guidelines for reporting observational studies. International journal of surgery, 2014. 12(12): p. 1495-1499.

42. Gillespie, B.M., et al., Wound care practices: a survey of acute care nurses. J Clin Nurs, 2014. 23(17-18): p. 2618-26.

43. McCluskey, P. and G. McCarthy, Nurses' knowledge and competence in wound management. Vol. 8. 2012. 37-47.

44. Caron-Mazet, J., B. Roth, and J.C. Guillaume, [Prevalence and management of chronic wounds in 14 geriatric institutions of the Haut-Rhin]. Ann Dermatol Venereol, 2007. 134(8-9): p. 645-51.

45. Adejumo PO, I.R., Issues in Contemporary Wound Management: Evaluation of Knowledge and Practices among Nurses in Two Municipalities in Osun State, Nigeria. . Ann Nurs Pract 2016. 3(6): p. 1065.

46. Nuru, N., et al., Knowledge and practice of nurses towards prevention of pressure ulcer and associated factors in Gondar University Hospital, Northwest Ethiopia. BMC Nurs, 2015. 14: p. 34.

47. Zarchi, K., et al., Significant differences in nurses' knowledge of basic wound management-implications for treatment. Acta dermato-venereologica, 2014. 94(4): p. 403-407.

48. Dugdall, $\mathrm{H}$. and R. Watson, What is the relationship between nurses' attitude to evidence based practice and the selection of wound care procedures? J Clin Nurs, 2009. 18(10): p. 1442-50.

49. Welsh, L., Wound care evidence, knowledge and education amongst nurses: a semi-systematic literature review. International wound journal, 2018. 15(1): p. 53-61.

50. Dowsett, C., Use of TIME to improve community nurses' wound care knowledge and practice. Wounds uk, 2009. 5(3): p. 14-21.

51. Beshir, M.A., S.A. Woreta, and M. Kebede, Evidence-based practice among health professionals in hospitals of Northwest Ethiopia: a cross-sectional study. International journal of evidence-based healthcare, 2017. 15(4): p. 161-170.

52. Wassie, M.A., et al., Evidence-based practice and its associated factors among medical laboratory professionals in West Amhara hospitals, Northwest Ethiopia. International journal of evidence-based healthcare, 2018. 16(1): p. 66-72.

\section{Tables}

Table 1: Socio demographic characteristics of nurses at tertiary referal hospital, 2018. 


\begin{tabular}{|c|c|c|}
\hline Variables & Number & Percent \% \\
\hline \multirow[t]{3}{*}{ Age } & 123 & $67.6 \%$ \\
\hline & 44 & $24.2 \%$ \\
\hline & 15 & $8.2 \%$ \\
\hline Sex & 86 & $47.3 \%$ \\
\hline Female & 96 & $52.7 \%$ \\
\hline Clinical experience $1-5 \mathrm{yr}$ & 87 & $47.8 \%$ \\
\hline $6-10 \mathrm{yr}$ & 65 & $35.7 \%$ \\
\hline$>10 \mathrm{yr}$ & 30 & $16.5 \%$ \\
\hline Married & 119 & $65.4 \%$ \\
\hline \multirow[t]{2}{*}{ status } & 57 & $31.3 \%$ \\
\hline & 6 & $3.2 \%$ \\
\hline Educational status Diploma & 42 & $23.1 \%$ \\
\hline Bsc \&above & 140 & $76.9 \%$ \\
\hline \multicolumn{3}{|l|}{ Training on wound care } \\
\hline Yes & 50 & $27.5 \%$ \\
\hline No & 132 & $72.5 \%$ \\
\hline
\end{tabular}

Yr, year of experience

Table 2: knowledge of nurses regarding to wound care who working at tertiary Ethiopian hospital, 2018. 


\begin{tabular}{|c|c|c|c|}
\hline \multirow[t]{2}{*}{ Variable } & Yes & No & Don't \\
\hline & No (\%) & No (\%) & No $(\%)$ \\
\hline $\begin{array}{l}\text { Immobility, impaired nutrition, and location of the wound } \\
\text { are risk factors for wound infection }\end{array}$ & 172(94.5\%) & $8(4.4 \%)$ & $2(1.1 \%)$ \\
\hline Wet therapy is the "gold standard" for chronic wounds & $118(64.8 \%)$ & $46(25.3 \%)$ & 18(9.9\%) \\
\hline wound must be evaluated by the health professional, & $54(29.7 \%)$ & $127(69.8 \%)$ & $1(0.5 \%)$ \\
\hline $\begin{array}{l}\text { Wound care is a cumulative process that comprises } \\
\text { observation, data collection and evolution }\end{array}$ & $151(83 \%)$ & $26(14.3 \%)$ & $5(2.7 \%)$ \\
\hline signs of infection may not be present in chronic wound & $83(83(45.6 \%)$ & $\begin{array}{l}96(52.7 \%) \\
3(1.6)\end{array}$ & \\
\hline $\begin{array}{l}\text { Wound coverage should be based on characteristic of } \\
\text { deathbed }\end{array}$ & $130(71.4 \%)$ & $39(21.4 \%)$ & $13(7.1 \%)$ \\
\hline \multicolumn{4}{|l|}{ presence of devitalized tissue) } \\
\hline pressure ulcer is easily identified in people of dark skin & $79(43.4 \%)$ & $100(54.9 \%)$ & $3(1.6 \%)$ \\
\hline Enzymes are effective in the removal of devitalized tissue & $114(62.6 \%)$ & $42(23.1 \%)$ & $26(14.3 \%)$ \\
\hline PVPI is indicated to clean chronic wounds & $40(22 \%)$ & $83(45.6 \%)$ & $59(32.4 \%)$ \\
\hline Wet gauze are more indicated for treating chronic wounds & $111(61 \%)$ & $69(37.9)$ & $2(1.1 \%)$ \\
\hline The swab is dipped in wound drainage during culture & $142(78 \%)$ & $31(17 \%)$ & $9(4.9 \%)$ \\
\hline Nurses are authorized to use conservative debridement & $131(72 \%)$ & $48(26.4 \%)$ & $3(1.6 \%)$ \\
\hline Braden scale is used to assess the risk of vascular ulcer & $119(65.4 \%)$ & $23(12.6 \%)$ & $40(22 \%)$ \\
\hline $\begin{array}{l}\text { Irrigation removes debris from wound better than } \\
\text { swabbing }\end{array}$ & 135(74.2\%) & $38(20.9 \%)$ & $9(4.9 \%)$ \\
\hline Recommended pressure for irrigation is $15 \mathrm{psi}$ & $86(47.3 \%)$ & $25(13.7 \%)$ & $71(39 \%)$ \\
\hline
\end{tabular}

Psi: pounds per square inch

Table 3: Practice of nurses regarding to wound care working at tertiary referral hospital, 2018. 


\begin{tabular}{|lllll|}
\hline Variable & Always & Usually & Sometims & Never \\
& No (\%) & No (\%) & No (\%) & No (\% \\
\hline $\begin{array}{l}\text { use the same dressing type for the entire wound } \\
\text { healing process }\end{array}$ & $38(20.9 \%)$ & $41(22.5 \%)$ & $35(19.2 \%)$ & $68(37.4 \%)$ \\
\hline $\begin{array}{l}\text { Treatment plans changes as when wound fills } \\
\text { with granulation tissue and epithelization }\end{array}$ & $89(48.9 \%)$ & $57(31.3 \%)$ & $28(15.4 \%)$ & $8(4.4 \%)$ \\
\hline Use foam dressing deep for exuding wounds & $79(43.4 \%)$ & $68(37.4 \%)$ & $17(9.3 \%)$ & $18(9.9 \%)$ \\
\hline Hydrogels, hydrocolloid are used & $33(18.1 \%)$ & $41(22.5 \%)$ & $74(40.7 \%)$ & $34(18.7 \%)$ \\
\hline Use hydrogen peroxide for wound cleansing & $39(21.4 \%)$ & $47(25.8 \%)$ & $79(43.4 \%)$ & $17(9.3 \%)$ \\
\hline Use water for wound cleansing & $19(10.4 \%)$ & $20(11.0 \%)$ & $8(4.4 \%)$ & $135(74.2 \%)$ \\
\hline Use normal saline for wound cleansing & $105(57.8 \%)$ & $65(35.7 \%)$ & $8(4.4 \%)$ & $4(2.2 \%)$ \\
\hline Positioning suitable for the wound of the patient & $114(62.6 \%)$ & $53(29.1 \%)$ & $12(6.6 \%)$ & $3(1.6 \%)$ \\
\hline Determining the localization of the wound & $99(54.4 \%)$ & $59(32.4 \%)$ & $22(12.1 \%)$ & $2(1.1 \%)$ \\
\hline Daily observing the wound in terms of flow, rush & $111(61.0 \%)$ & $51(28.0 \%)$ & $16(8.8 \%)$ & $4(2.2 \%)$ \\
\hline Evaluating the drains for color & $96(52.7 \%)$ & $66(36.3 \%)$ & $16(8.8 \%)$ & $4(2.2 \%)$ \\
\hline Evaluating the drains for amount & $79(43.4 \%)$ & $58(31.9 \%)$ & $32(17.6 \%)$ & $13(7.1 \%)$ \\
\hline Evaluating the drains for odor & $99(54.4 \%)$ & $49(26.9 \%)$ & $29(15.9 \%)$ & $5(2.7 \%)$ \\
\hline Evaluating the wound area for sensitivity and & $109(59.9 \%)$ & $54(29.7 \%)$ & $17(9.3 \%)$ & $2(1.1 \%)$ \\
\hline pain & $91(50 \%)$ & $64(35.2 \%)$ & $16(8.8 \%)$ & $11(6 \%)$ \\
\hline Encouraging the patient for early mobilization & $86(47.3 \%)$ & $61(33.5 \%)$ & $28(15.4 \%)$ & $7(3.8 \%)$ \\
\hline Providing adequate hydration of the patient & $124(68.1 \%)$ & $48(26.4 \%)$ & $9(4.9 \%)$ & $1(0.5 \%)$ \\
\hline Making suggestions about nutrition of the patient & & & & \\
\hline
\end{tabular}

Table 4: pre discharge education on wound care at tertiary referral hospital, 2018. 


\begin{tabular}{|lllll|}
\hline Variable & Always & Usually & Sometimes & Never \\
& & & & \\
& No (\%) & No (\%) & No (\%) & No (\% \\
\hline Informing about wound care & $144(79.1 \%)$ & $34(18.7 \%)$ & $2(1.1 \%)$ & $2(1.1 \%)$ \\
\hline Informing about the time of the suture removed & $119(65.4 \%)$ & $38(20.9 \%)$ & $24(13.2 \%)$ & $1(0.5 \%)$ \\
\hline $\begin{array}{l}\text { Informing about the time of the body bath } \\
\text { Informing about the precautions to prevent }\end{array}$ & $74(40.7 \%)$ & $57(31.3 \%)$ & $39(21.4 \%)$ & $12(6.6 \%)$ \\
\hline constipation & $78(42.9 \%)$ & $67(36.8 \%)$ & $35(19.2 \%)$ & $2(1.1 \%)$ \\
\hline $\begin{array}{l}\text { Informing about the food groups for faster wound } \\
\text { healing }\end{array}$ & $122(67.0 \%)$ & $49(29.9 \%)$ & $10(5.5 \%)$ & $1(0.5 \%)$ \\
\hline $\begin{array}{l}\text { Giving hygiene education to prevent infection on } \\
\text { the incision area }\end{array}$ & $119(65.4 \%)$ & $52(28.6 \%)$ & $9(4.9 \%)$ & $2(1.1 \%)$ \\
\hline $\begin{array}{l}\text { Informing about the medications with negative } \\
\text { effects on wound healing }\end{array}$ & & & & \\
\hline
\end{tabular}

Table 5: association factors of on the Level of knowledge of nurses on wound care in Ethiopia, 2018 


\begin{tabular}{|c|c|c|c|c|c|c|c|}
\hline \multirow[t]{2}{*}{ Variable } & \multirow[t]{2}{*}{ Category } & \multicolumn{2}{|c|}{ Level of knowledge } & \multicolumn{3}{|c|}{ POR } & \multirow{2}{*}{$\begin{array}{l}\mathrm{P} \text { - } \\
\text { Value }\end{array}$} \\
\hline & & Good & Moderate & Poor & CPOR[95\%Cl] & aPOR[95Cl] & \\
\hline \multirow[t]{3}{*}{ Age } & $20-30$ & 20 & 46 & 57 & $\begin{array}{l}0.71 \\
(0.684,1.32)\end{array}$ & - & \\
\hline & $31-40$ & 10 & 20 & 14 & $\begin{array}{c}1.81 \\
(0.95,1.24)\end{array}$ & - & \\
\hline & $>40$ & 19 & 31 & 36 & 1.00 & - & \\
\hline \multirow[t]{2}{*}{ Sex } & Male & 15 & 41 & 40 & $\begin{array}{c}1.9 \\
(0.41,0.68)\end{array}$ & - & \\
\hline & Female & 15 & 41 & 40 & 1.00 & & \\
\hline \multirow[t]{3}{*}{$\begin{array}{l}\text { Clinical } \\
\text { experience }\end{array}$} & $1 \mathrm{mon}-5 \mathrm{yr}$ & 14 & 36 & 37 & $\begin{array}{c}0.26 \\
(0.55,1.00)\end{array}$ & - & \\
\hline & $6-10 \mathrm{yr}$ & 13 & 23 & 29 & $\begin{array}{c}0.45 \\
(0.42,1.20)\end{array}$ & - & \\
\hline & $>10 \mathrm{yr}$ & 7 & 13 & 10 & 1.00 & & \\
\hline \multirow[t]{3}{*}{ Marital status } & Married & 18 & 52 & 49 & $1.58)^{2.98(0.48,}$ & - & \\
\hline & Single & 14 & 18 & 25 & $1.15(0.33,1.82)$ & - & \\
\hline & Divorced & 2 & 2 & 2 & 1.00 & & \\
\hline \multirow[t]{2}{*}{$\begin{array}{l}\text { Educational } \\
\text { status }\end{array}$} & Diploma & 6 & 17 & 19 & $1.72)^{0.25(0.57}$ & - & \\
\hline & Bsc\& above & 28 & 55 & 57 & 1.00 & & \\
\hline \multirow{3}{*}{$\begin{array}{l}\text { Working } \\
\text { experience in } \\
\text { this center }\end{array}$} & $<5 \mathrm{yr}$ & 26 & 48 & 63 & $\begin{array}{l}0.57(0.33 \\
0.82)^{*}\end{array}$ & $\begin{array}{l}0.42(0.11 \\
0.99)^{\star}\end{array}$ & $0.03^{\star *}$ \\
\hline & $5-10 \mathrm{yr}$ & 5 & 20 & 11 & $\begin{array}{c}1.9 \\
(0.23,1.54)\end{array}$ & $\begin{array}{l}4.78 \\
(0.38,2.45)\end{array}$ & 0.15 \\
\hline & $>10 \mathrm{yr}$ & 3 & 4 & 2 & 1.00 & 1.00 & \\
\hline \multirow[t]{5}{*}{ Clinical setting } & Surgical & 5 & 17 & 33 & $\begin{array}{l}5.23(1.69 \\
1.85)^{\star}\end{array}$ & $\begin{array}{l}5.45 \\
(1.61,2.21)\end{array}$ & $0.001 *$ \\
\hline & Orthopedics & 4 & 15 & 16 & $\begin{array}{l}0.84(0.13 \\
1.54)^{\star}\end{array}$ & $\begin{array}{l}1.15 \\
(0.09,1.61)\end{array}$ & 0.08 \\
\hline & Medical & 2 & 11 & 8 & $\begin{array}{l}0.08(0.45 \\
1.49)\end{array}$ & $\begin{array}{l}0.16 \\
(0.52,1.45)\end{array}$ & 0.36 \\
\hline & Emergency & 12 & 9 & 5 & $\begin{array}{l}0.5(0.01 \\
1.82)^{*}\end{array}$ & $\begin{array}{l}0.26 \\
(0.03,0.18)^{*}\end{array}$ & $0.04^{*}$ \\
\hline & Others & 11 & 20 & 14 & 1.00 & 1.00 & \\
\hline
\end{tabular}




\begin{tabular}{lccccccc|}
$\begin{array}{l}\text { Training on } \\
\text { wound care }\end{array}$ & Yes & 5 & 26 & 19 & $\begin{array}{c}1.85 \\
(.130,1.097) *\end{array}$ & $\begin{array}{l}12.5 \\
(0.16,1.18)\end{array}$ \\
\cline { 2 - 7 } & No & 29 & 46 & 57 & 1.00 & 1.00 \\
\hline
\end{tabular}

*Statistical significance at $p$ value $<0.25$ in bivariate and $<0.05$ in multivariable analysis.

Others- Obs/gyn, Urology, Neurology, Geriatrics, Nephrology, Hematology and Pediatrics

Table 6: Associated factors of the Level of practice of nurses on wound care in Ethiopia, 2018 


\begin{tabular}{|c|c|c|c|c|c|c|c|}
\hline \multirow[t]{2}{*}{ Variable } & \multirow[t]{2}{*}{ Category } & \multicolumn{3}{|c|}{ Level of practice } & \multirow[b]{2}{*}{ CPOR[95\%Cl] } & \multirow[b]{2}{*}{ aPOR[95\%Cl] } & \multirow[b]{2}{*}{$\begin{array}{l}\text { P- } \\
\text { Value }\end{array}$} \\
\hline & & Good & Moderate & Poor & & & \\
\hline \multirow[t]{3}{*}{ Age } & $20-30$ & 10 & 40 & 73 & $\begin{array}{l}1.27(0.23 \\
1.79) *\end{array}$ & $1.09(0.96,1.44)$ & 0.75 \\
\hline & $31-40$ & 3 & 12 & 29 & $\begin{array}{c}3.48 \\
(0.08,2.19) *\end{array}$ & $0.45(0.85,2.19)$ & 0.38 \\
\hline & $>40$ & 4 & 4 & 7 & 1.00 & 1.00 & \\
\hline \multirow[t]{2}{*}{ Sex } & Male & 7 & 26 & 53 & $\begin{array}{l}0.73 \\
(0.43,1.74)\end{array}$ & - & \\
\hline & Female & 10 & 30 & 56 & 1.00 & - & \\
\hline \multirow[t]{3}{*}{$\begin{array}{l}\text { Marital } \\
\text { status }\end{array}$} & Married & 7 & 33 & 79 & $\begin{array}{l}3.81 \\
(0.40,2.69)^{*}\end{array}$ & & \\
\hline & Single & 8 & 22 & 27 & $\begin{array}{l}0.66(1.23 \\
1.92)\end{array}$ & & \\
\hline & Divorced & 2 & 1 & 3 & 1.00 & 1.00 & \\
\hline \multirow[t]{2}{*}{$\begin{array}{l}\text { Educational } \\
\text { status }\end{array}$} & Diploma & 6 & 11 & 25 & $\begin{array}{c}5.12 \\
(0.8,1.54)\end{array}$ & - & \\
\hline & BSc \&above & 11 & 45 & 84 & 1.00 & & \\
\hline \multirow[t]{3}{*}{$\begin{array}{l}\text { Clinical } \\
\text { experience }\end{array}$} & $1-5 \mathrm{yr}$ & 5 & 27 & 55 & $0.12(0.28,1.34)^{\star}$ & $1.9(0.56,2.32)$ & 0.23 \\
\hline & $6-10 \mathrm{yr}$ & 7 & 20 & 38 & $\begin{array}{l}0.94(0.56 \\
1.12)\end{array}$ & $2.75(0.24,1.36)$ & 0.92 \\
\hline & $>10 \mathrm{yr}$ & 5 & 9 & 16 & 1.00 & 1.00 & \\
\hline \multirow{3}{*}{$\begin{array}{l}\text { Working } \\
\text { experience } \\
\text { in this } \\
\text { center }\end{array}$} & $<5 \mathrm{yr}$ & 15 & 42 & 80 & $\begin{array}{l}0.2(0.83 \\
1.73)\end{array}$ & $0.75(0.11,1.75)$ & 0.66 \\
\hline & $5-10 y r$ & 1 & 10 & 25 & $\begin{array}{l}4.62(0.43 \\
2.43)^{\star}\end{array}$ & $\begin{array}{l}4.54 \\
(1.05,2.81)^{\star}\end{array}$ & $0.01 *$ \\
\hline & $>10 \mathrm{yr}$ & 1 & 4 & 4 & 1.00 & 1.00 & \\
\hline \multirow[t]{5}{*}{$\begin{array}{l}\text { Clinical } \\
\text { setting }\end{array}$} & Surgical & 2 & 18 & 35 & $0.7(0.1,1.46)^{\star}$ & $\begin{array}{l}0.08 \\
(0.35,1.41)\end{array}$ & 0.24 \\
\hline & Orthopedics & 2 & 8 & 25 & $\begin{array}{l}3.48(0.06 \\
1.89)^{\star}\end{array}$ & $1.99(0.1,1.87)$ & 0.08 \\
\hline & Medical & 2 & 5 & 14 & $0.9(0.34,1.76)^{\star}$ & $\begin{array}{l}0.36 \\
(0.74,1.58)\end{array}$ & 0.48 \\
\hline & Emergency & 3 & 11 & 12 & $\begin{array}{l}2.12 \text { (0.87, } \\
0.96)\end{array}$ & $\begin{array}{l}2.75 \\
(0.93,1.14)\end{array}$ & 0.89 \\
\hline & Others & 8 & 14 & 23 & 1.00 & 1.00 & \\
\hline
\end{tabular}




\begin{tabular}{|c|c|c|c|c|c|c|c|}
\hline \multirow[t]{2}{*}{$\begin{array}{l}\text { Training on } \\
\text { wound care }\end{array}$} & Yes & 6 & 13 & 31 & $\begin{array}{l}1.97 \\
(0.03,0.53)^{\star}\end{array}$ & $1.9(0.59,0.87)$ & $0.025^{\star}$ \\
\hline & No & 11 & 43 & 78 & 1.00 & 1.00 & \\
\hline \multirow[t]{3}{*}{$\begin{array}{l}\text { Level of } \\
\text { knowledge }\end{array}$} & Good & 10 & 12 & 12 & $\begin{array}{l}6.45(0.64 \\
2.23)^{\star}\end{array}$ & $\begin{array}{l}5.56 \\
(1.08,2,26)^{*}\end{array}$ & $0.003 *$ \\
\hline & Moderate & 4 & 19 & 49 & $\begin{array}{l}2.43 \text { (0.51, } \\
0.85)\end{array}$ & $\begin{array}{l}2.75 \\
(0.66,1.76)\end{array}$ & 0.87 \\
\hline & Poor & 3 & 25 & 48 & 1.00 & 1.00 & \\
\hline
\end{tabular}

*Statistical significance at $p$ value $<0.05$, Mon- month

Figures 


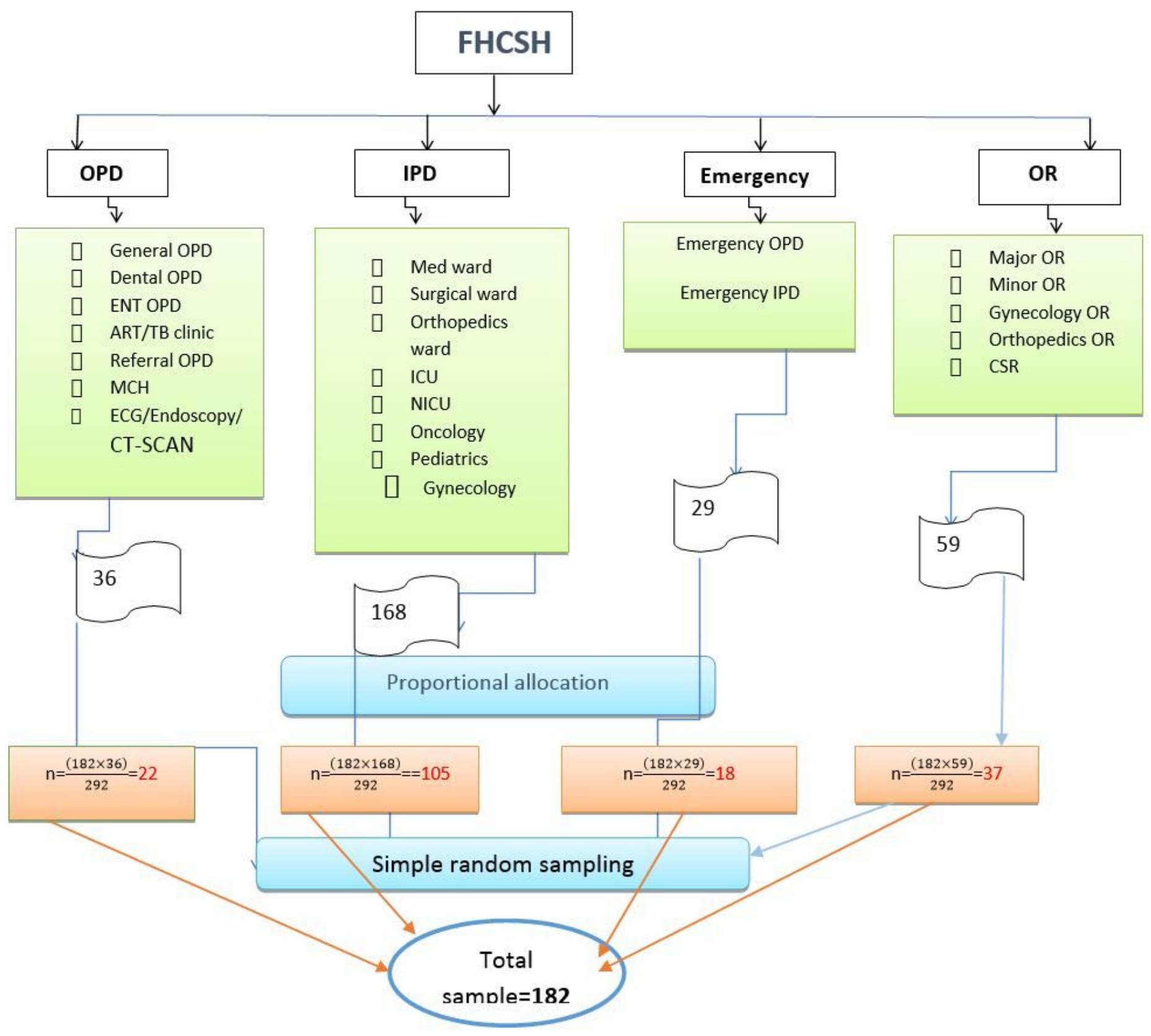

Figure 1

Schematic presentation of sampling procedure on knowledge and practice of nurses towards wound care in Felege Hiwot specialized Hospital, Ethiopia, 2018 


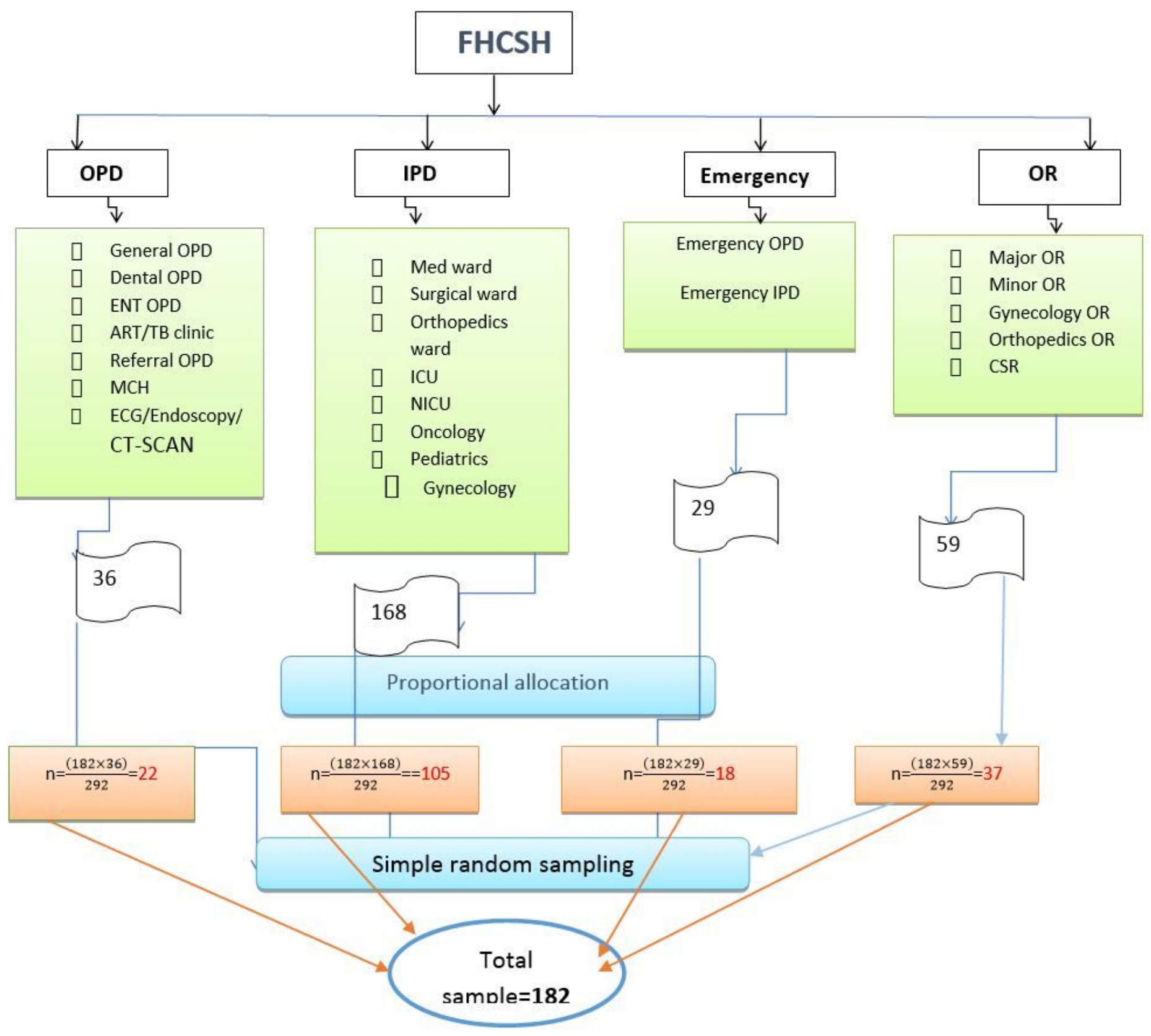

Figure 1

Schematic presentation of sampling procedure on knowledge and practice of nurses towards wound care in Felege Hiwot specialized Hospital, Ethiopia, 2018 


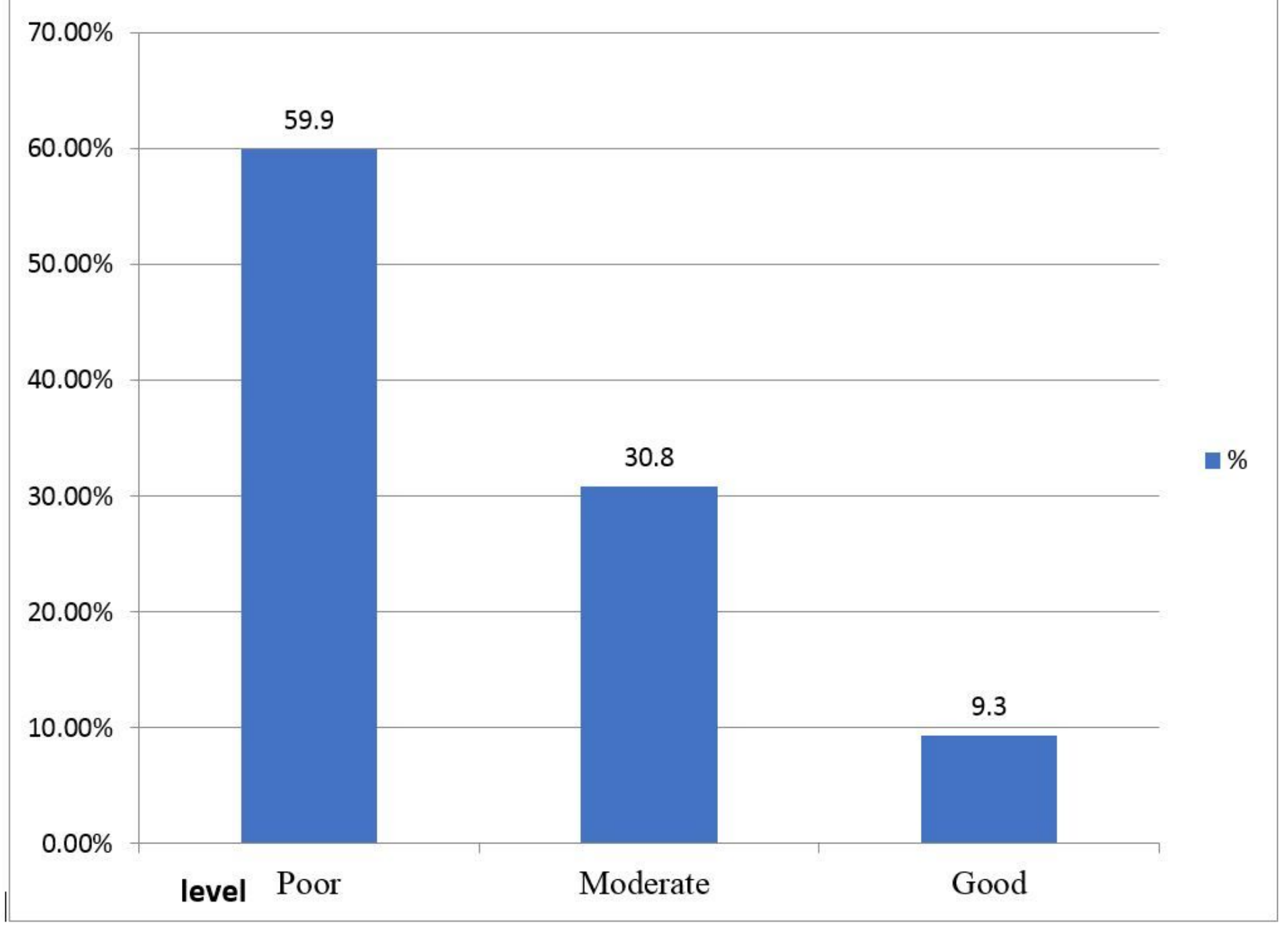

Figure 2

Practice level of nurses regarding to wound healing and care in FHCSH 


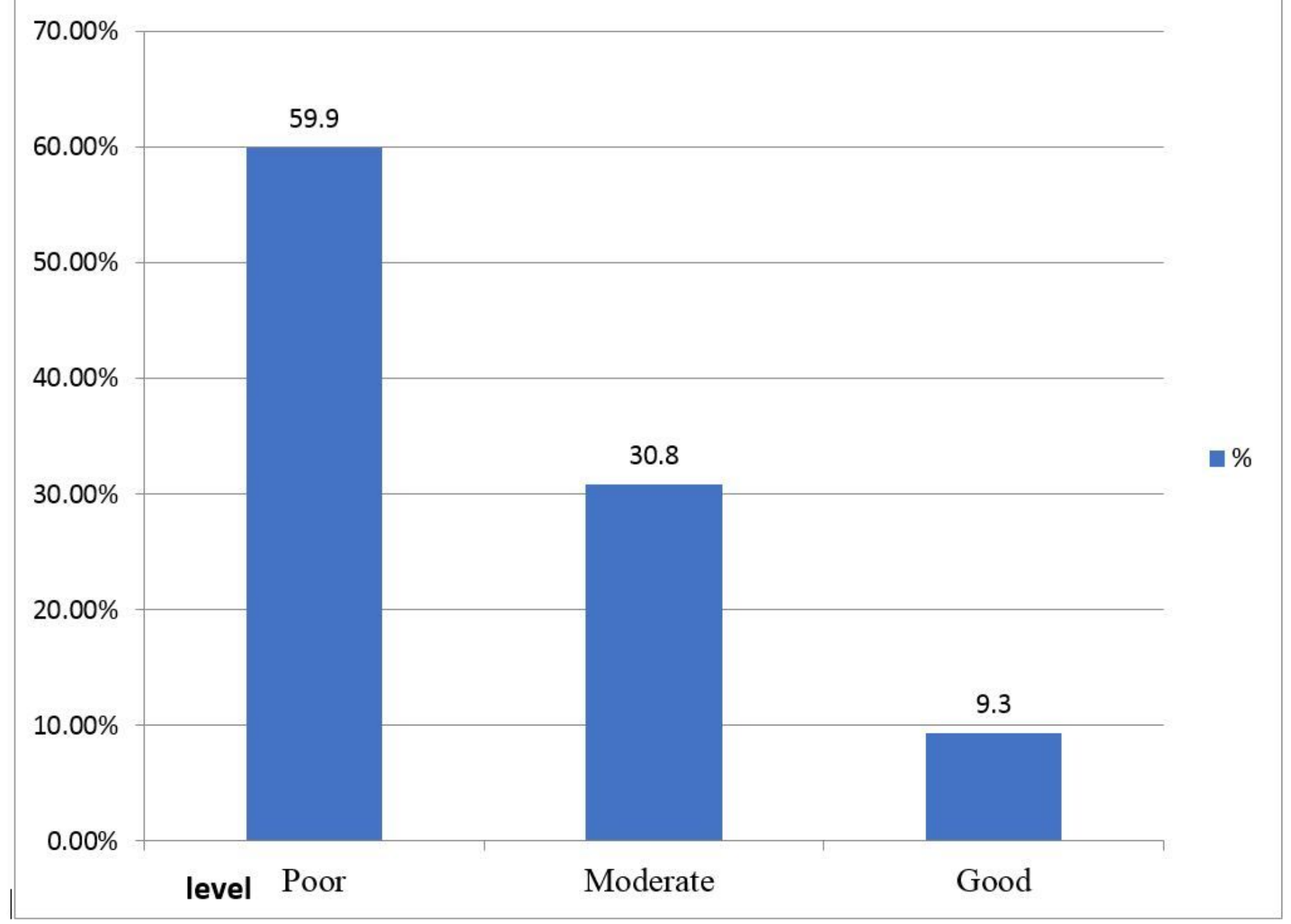

Figure 2

Practice level of nurses regarding to wound healing and care in FHCSH

\section{Supplementary Files}

This is a list of supplementary files associated with this preprint. Click to download.

- STROBEchecklistforwoundcare.docx

- STROBEchecklistforwoundcare.docx 